\title{
Mechanisms of precocious puberty induced in male rats by pituitary grafts*
}

\author{
R. Aguilar, C. Bellido, J. E. Sánchez-Criado and E. Aguilar \\ Department of Physiology, Faculty of Medicine, Córdoba University, 14004 Córdoba, Spain
}

\begin{abstract}
Summary. Male rats were grafted on Day 21 of age with 'young' (21 days old) or 'adult' ( 90 days old) pituitary glands and then treated daily with $4 \mathrm{mg}$ bromocriptine/ $\mathrm{kg}$ or vehicle. Plasma samples were obtained on Days 21,25 and 35 and when balanopreputial separation occurred. Both types of grafts advanced the age at which balanopreputial separation occurred and increased prolactin concentrations. Bromocriptine treatment reduced the prolactin values in both grafted groups, but did not block the advancement of puberty in rats treated with 'young' pituitary grafts.

These results suggest the existence of two possible mechanisms in precocious puberty induced by pituitary grafts: one is prolactin-dependent (when 'adult' pituitary glands were used) and the other not directly related to prolactin (when 'young' pituitary glands were used).
\end{abstract}

Keywords: balano-preputial separation; pituitary graft; prolactin; bromocriptine; testosterone; rat

\section{Introduction}

It is well-known that hyperprolactinaemia induces precocious puberty in female (Advis \& Ojdeda, 1978; Advis et al., 1981) and male (de Jong \& van der Schoot, 1979) rats. In female rats, puberty can be advanced by grafting a pituitary gland from an 'adult' donor ( 90 days old) and is associated with an increase in plasma prolactin concentrations and can be blocked by bromocriptine treatment. However, the advancement induced by grafting a pituitary gland from a 'young' donor (21 days old) was not associated with increased prolactin concentrations and cannot be blocked by bromocriptine. These results suggested the existence of two possible mechanisms in precocious puberty induced by pituitary gland grafts: one being prolactin-dependent and the other not directly related to prolactin (Gonzalez et al., 1986).

In the present work we have tried to confirm whether these two possible mechanisms are present in male rats, using balano-preputial separation as the index of puberty (Korenbrodt et al., 1977).

\section{Materials and Methods}

Animals. The animals used in this work were 'true littermate' male Wistar rats (Adler, 1986) born in our laboratory. They were kept under conditions of controlled light ( $12 \mathrm{~h}$ light: $12 \mathrm{~h}$ darkness; lights on at $07: 00 \mathrm{~h}$ ) and temperature $\left(20^{\circ} \mathrm{C}\right)$ and Sanders rat chow and tap water were available ad libitum. Litters born on the same day were marked and thoroughly mixed and returned to the mothers in groups of 8 per mother. Animals were weaned on Day 21 and housed in group cages (4-5 per cage).

Surgical procedures. Pituitary gland grafting was performed under light ether anaesthesia on Day 21 . The pituitary gland of a littermate ('young donor') or an 'adult' donor (90-day-old brother) was transplanted under the right kidney capsule. Sham-operated animals grafted with a piece of adipose tissue instead of a pituitary gland served as controls. At autopsy the pituitary transplant was examined for size, colour and vascularity to confirm that it was functional.

*Reprints request to Dr E. Aguilar. 
Bromocriptine treatment. Bromocriptine mesylate (Sandoz, Basle, Switzerland) was dissolved in saline $(0 \cdot 154 \mathrm{M}-$ $\mathrm{NaCl}$ ) with $10 \%$ ethanol. Beginning on Day 21 , animals received bromocriptine at $4 \mathrm{mg} / \mathrm{kg}$ given as two injections at 10:00 and 22:00 $\mathrm{h}$ or vehicle daily. Injections were performed subcutaneously.

Experimental procedures. In Exp. 1, males (21 days of age) received a pituitary gland from a littermate or an 'adult' donor under the right kidney capsule. Animals were checked daily and the age and body weight of all the animals were recorded on the day of balano-preputial separation.

In Exp. 2, males (2l days of age) received a pituitary gland from a littermate or an 'adult' donor under the right kidney capsule. Immediately afterwards, bromocriptine $(4 \mathrm{mg} / \mathrm{kg})$ or vehicle treatment began. The age and the body weight on the day of balano-preputial separation were recorded in all animals. Blood samples were obtained before daily injections of bromocriptine or vehicle at 10:00 h on Days $21,25,35$ and at decapitation performed on the day of balano-preputial separation. Samples were obtained by jugular venepuncture after light ether anaesthesia as described previously (Gonzalez et al., 1986).

Hormonal assays. Plasma samples, obtained by centrifugation of blood for $20 \mathrm{~min}$ at $1650 \mathrm{~g}$, were immediately frozen and stored at $-20^{\circ} \mathrm{C}$ until assayed. Plasma prolactin concentrations were determined by a double radioimmunoassay method using a kit from NIAMDD (Bethesda, Maryland, U.S.A.). Rat-Prl-I-4 was labelled with ${ }^{125}$ I by the chloramine $T$ method (Greenwood et al., 1963). The prolactin plasma values are expressed in $\mathrm{ng} / \mathrm{ml}$ of the reference preparation Rat-Prl-RP-3. Testosterone was determined as previously described (Rodriguez-Padilla et al., 1987). To avoid interassay variations, all samples were measured in duplicate, in the same assay. Intra-assay variabilities were respectively $9 \%$ and $5 \%$ for prolactin and testosterone, the limits of sensitivity being $0 \cdot 1 \mathrm{ng}$ and $5 \mathrm{pg} /$ tube, respectively.

Statistics. Values are given as means \pm s.e.m. Differences between groups were analysed using an ANOVA followed by a Duncan new multiple range test.

\section{Results}

Male rats grafted with 'young' pituitary glands showed precocious balano-preputial separation, occurring at a lower weight, than in sham-operated controls. Bromocriptine treatment blocked only the effect induced by 'adult' transplants (Table 1).

Table 1. Effects of bromocriptine (from the age of 21 days until the time of balano-preputial separation) on the precocious puberty induced by a 21 -dayold (young) or a 90-day-old (adult) pituitary gland graft

\begin{tabular}{lccc}
\hline Group & $\begin{array}{c}\text { No. of } \\
\text { rats }\end{array}$ & $\begin{array}{c}\text { Age } \\
\text { (days) }\end{array}$ & $\begin{array}{c}\text { Body weight } \\
\text { (g) }\end{array}$ \\
\hline Experiment 1 & & & \\
$\quad$ (1) Sham-operated & 13 & $40 \cdot 38 \pm 0 \cdot 34$ & $142 \pm 8$ \\
(2) 'Young' graft & 15 & $36 \cdot 46 \pm 0 \cdot 13^{*}$ & $116 \pm 4^{*}$ \\
(3) 'Adult' graft & 15 & $36 \cdot 80 \pm 0 \cdot 18^{*}$ & $120 \pm 6^{*}$ \\
Experiment 2 & 12 & $41 \cdot 25 \pm 0 \cdot 26$ & $148 \pm 6 \dagger$ \\
(4) Sham-operated + vehicle & 11 & $39 \cdot 00 \pm 0 \cdot 42^{*}$ & $133 \pm 4$ \\
(5) 'Young' graft + vehicle & 8 & $38 \cdot 37 \pm 0 \cdot 28^{*}$ & $125 \pm 6$ \\
(6) 'Adult' graft + vehicle & 10 & $40 \cdot 90 \pm 0 \cdot 24$ & $143 \pm 4$ \\
(7) Sham-operated + bromocriptine & 12 & $37 \cdot 91 \pm 0 \cdot 23^{*}$ & $112 \pm 3$ \\
(8) 'Young' graft + bromocriptine & 9 & $40 \cdot 66 \pm 0 \cdot 77^{* *}$ & $133 \pm 8$ \\
(9) 'Adult' graft + bromocriptine & & & \\
\hline
\end{tabular}

Values are given as means \pm s.e.m.

${ }^{*} P<0.01$ vs Group 1 (Exp. 1) or Group 4 (Exp. 2); ${ }^{*} P<0.01$ vs Group 8; $\dagger P<0.01$ (grafted $v s$ sham-operated animals) (ANOVA followed by Duncan new multiple range test).

Male rats grafted with an 'adult' or 'young' pituitary gland showed hyperprolactinaemia, the plasma prolactin concentrations being higher in animals grafted with 'adult' pituitary glands than in those grafted with 'young' pituitary glands. Bromocriptine treatment reduced the prolactin values in both types of animals (Fig. 1). 


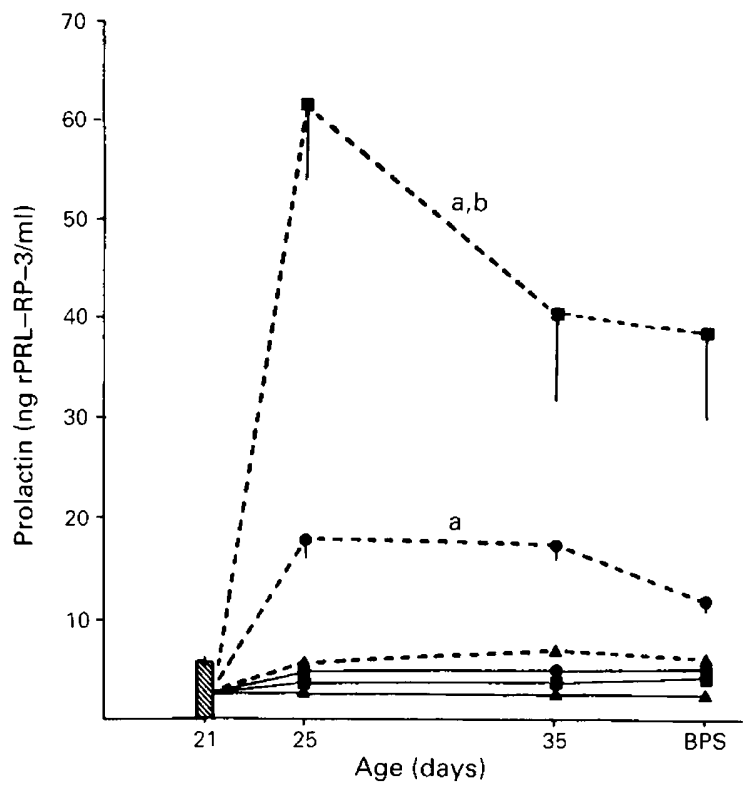

Fig. 1. Plasma prolactin concentrations in animals grafted on Day 21 of age with one 'adult' $(\boldsymbol{C})$ or 'young' $(\boldsymbol{O})$ pituitary or sham-operated $(\mathbf{\Delta})$. Animals were treated until balanopreputial separation (BPS) with bromocriptine $(4 \mathrm{mg} / \mathrm{kg} /$ day) $(-)$ or vehicle $(---)$. The numbers of animals were as indicated in Table 1 (Exp. 2). Values are expressed as means \pm s.e.m. ${ }^{a} P<0.01 v s$ other groups; ${ }^{b} P<0.01 \mathrm{vs}$ other groups (ANOVA followed by Duncan new multiple range test).

Plasma testosterone concentrations at balano-preputial separation were similar in rats shamoperated $(1224 \pm 319 \mathrm{pg} / \mathrm{ml})$, or those grafted with 'young' $(782 \pm 150 \mathrm{pg} / \mathrm{ml})$ or 'adult' $(799 \pm 149 \mathrm{pg} / \mathrm{ml})$ pituitary glands. Bromocriptine treatment reduced plasma testosterone concentrations in all groups, although the effect was only significant $(P<0.05)$ in animals grafted with 'adult' pituitary glands $(451 \pm 55$ vs $799 \pm 149 \mathrm{pg} / \mathrm{ml}$ in similar animals treated with vehicle $)$.

\section{Discussion}

The main objective of this work was to analyse the difference, if any, in the mechanism by which pituitary grafts of different donor age advanced puberty in male rats. Our results showed that prepubertal male rats grafted with one 'young' or 'adult' pituitary exhibited precocious balano-preputial separation. The degree of advancement was less than described by de Jong \& van der Schoot (1979), perhaps due to the reduced number of pituitary glands grafted in our experiments.

The animals grafted with an 'adult' pituitary developed a greater increase in plasma prolactin concentrations than did those grafted with a 'young' pituitary gland. The low efficiency shown by 'young' pituitary glands in releasing prolactin when grafted has been previously described for females (Gonzalez et al., 1986) and could be explained by their low prolactin content (Döhler et al., 1977). Nevertheless, in spite of the different increases in prolactin concentrations, there was a similar advancement in puberty. At least two explanations are possible: (1) increases in prolactin concentrations above a 'threshold' induces the precocious puberty independent of the absolute plasma values and (2) other factors different from prolactin are involved in precocious puberty. The normal balano-preputial separation in sham-operated animals treated with bromocriptine 
indicated that, even with the lowest concentrations of prolactin obtained by this treatment, puberty occurs at the physiological time.

In the animals grafted with 'adult' pituitary glands, the increase in plasma prolactin values and the blockade of precocious puberty after bromocriptine treatment suggested that prolactin release from the graft was responsible for the changes observed in balano-preputial separation. Assuming that the effect of bromocriptine is only on pituitary prolactin secretion (Richardson \& Donatsch, 1985; Steger \& Morgan, 1985), the inability of bromocriptine to block precocious puberty induced by 'young' grafts suggested that the effect is mediated by a factor other than prolactin.

Plasma testosterone concentrations at the time of balano-preputial separation were similar in rats in Groups 4, 5 and 6 (all vehicle treated), agreeing with data from de Jong \& van der Schoot (1979) indicating that testosterone increased only in the early days after transplantation and was later normalized. Our results showing that bromocriptine treatment reduced plasma prolactin concentrations in animals grafted with 'adult' or 'young' pituitary glands below $5 \mathrm{ng} / \mathrm{ml}$, but modified testosterone plasma levels only in animals grafted with 'adult' pituitary glands, suggested a different action of bromocriptine treatment on testicular function.

In conclusion, the present results suggest that pituitary grafts advanced puberty in males, as well as in females (Gonzalez et al., 1986), by two possible mechanisms, one prolactin dependent and the other not directly related to prolactin, depending on the age of the pituitary graft. Our previous results (Aguilar et al., 1987) suggested that, at least in females, precocious puberty induced by 'young' pituitary glands is mediated by an early secretion of gonadotrophins after grafting, since FSH and LH increased $12 \mathrm{~h}$ afterwards, and also that the effect on puberty can be blocked by the administration of specific LH antiserum or by grafting pituitary glands depleted of gonadotrophins.

Since an early secretion of gonadotrophins has also been described in prepubertal females grafted with 'adult' pituitary glands (Advis \& Ojeda, 1979), a better interpretation of precocious puberty induced by pituitary grafts could be obtained by analysing the following: (a) the mechanism controlling gonadotrophin secretion from 'young' or 'adult' grafts; (b) the biological activity of gonadotrophins secreted, since different forms of LH with different biological and immunological activities have been reported for immature rats (ter Haar \& Wilson, 1978; Buckingham \& Wilson, 1985); and (c) the structure and biological actions of prolactin secreted by 'young' or 'adult' grafts.

This work has been supported by a grant from the CAICYT (Spain). We thank NIH for the radioimmunoassay materials for prolactin determinations; Dr G. D. Niswender (Colorado State University, Fort Collins, CO, U.S.A.) for the antiserum S 250 for testosterone determinations; Dr F. Gaytan and Miss T. Recio for technical work; and Ms Sullivan for assistance in the production of the manuscript.

\section{References}

Adler, R.A. (1986) The anterior pituitary-grafted rat: a valid model of Chronic Hyperprolactinemia. Endocr. Rev. 7, 302-313.

Advis, J.P. \& Ojeda, S.R. (1978) Hyperprolactinemiainduced precocious puberty in the female rat: ovarian site of action. Endocrinology 103, 924-935.

Advis, J.P. \& Ojeda, S.R. (1979) Acute and delayed effects of anterior pituitary transplants in inducing precocious puberty in the female rat. Biol. Reprod. 20, 879-887.

Advis, J.P., Richards, J.S. \& Ojeda, S.R. (1981) Hyperprolactinemia-induced precocious puberty: studies on the mechanism(s) by which prolactin enhances ovarian progesterone responsiveness to gonadotropins in prepuberal rats. Endocrinology 108, 1333-1342.
Aguilar, E., Pinilla, L., Gonzalez, D., López, F. \& Sánchez Criado, J. (1987). Mechanism of advanced puberty induced in female rats by grafting a "young" pituitary. J. Endocrinol. Invest. 10 (suppl. 3) OC27, Abstr.

Buckingham, J.C. \& Wilson, C.A. (1985) Peripubertal changes in the nature of LH. J. Endocr. 104, 173-177.

de Jong, R.A.P. \& van der Schoot, P. (1979) Advancement of sexual maturation in male rats by pituitary transplants. Biol. Reprod. 21, 1263-1271.

Döhler, K., Mühlen, A.V.Z. \& Döhler, U. (1977) Pituitary luteinizing hormone ( $\mathrm{LH})$, follicle stimulating hormone (FSH) and prolactin from birth to puberty in fenale and male rats. Acta endocr., Copenh. 85, $718-728$. 
Gonzalez, D., López, F., Sánchez Criado, J. \& Aguilar, E. (1986) Two possible mechanisms for precocious puberty induced in female rats by pituitary grafts. Neuroendocrinology 42, 323-327.

Greenwood, F.C., Hunter, W.M. \& Glover, J.S. (1963) The preparation of ${ }^{131} \mathrm{I}$-labelled human growth hormone of high specific radioactivity. Biochem. J. 89, 114-123.

Korenbrodt, C.C., Huhtaniemi, I.T. \& Weiner, R.I. (1977) Preputial separation as an external sign of pubertal development in the male rat. Biol. Reprod. 17, 298-303.

Richardson, B.P. \& Donatsch, P. (1985) Age-dependent effects of dopaminomimetic ergot compounds on sex steroid hormones in rats. In Dopamine and Neuro- endocrine Active Substances, pp. 91-103. Eds E. Del Pozo \& E. Flückiger. Academic Press, London.

Rodriguez-Padilla, M., Bellido, C., Pinilla, L. \& Aguilar, E. (1987) Secretion of LH in spontaneously hypertensive rats. J. Endocr. 113, 255-260.

Steger, R.W. \& Morgan, W.W. (1985) The dopaminergic control of pituitary hormone release. In Handbook of Pharmacologic Methodologies for the Study of the Neuroendocrine System, pp. 65-109. Eds R. W. Steger \& A. Johns. CRC Press, Boca Raton.

ter Haar, M.B. \& Wilson, C.A. (1978) Evidence for pleiomorphism of luteinizing hormone in prepubertal female rats. $J$. Endocr. 79, 133-134.

Received 21 December 1987 